\title{
Communication \\ Carbon-Supported Raney Nickel Catalyst for Acetone Hydrogenation with High Selectivity
}

\author{
Shuliang Lu, Jiajia Wu, Hui Peng and Yong Chen * \\ SINOPEC Beijing Research Institute of Chemical Industry, Beijing 100013, China; Lusl.bjhy@sinopec.com (S.L.); \\ wujj.bjhy@sinopec.com (J.W.); pengh.bjhy@sinopec.com (H.P.) \\ * Correspondence: chenyong_bhy.bjhy@sinopec.com
}

Received: 14 January 2020; Accepted: 11 February 2020; Published: 13 February 2020

\begin{abstract}
Catalysts with high selectivity play key roles in green chemistry. In this work, a granular Raney Ni catalyst using carbon as support (Raney Ni/C) was developed by mixing phenolic resin with $\mathrm{Ni}-\mathrm{Al}$ alloy, conducting carbonization at high temperature, and leaching with alkaline liquor. The as-prepared Raney Ni/C catalyst is suitable for use in fix-bed reactors. Moreover, it shows high activity and selectivity for catalytic acetone hydrogenation. For instance, at the reaction temperature of $120^{\circ} \mathrm{C}$, the conversion of acetone can reach up to $99.9 \%$ and the main byproduct methyl isobutylcarbinol (MIBC) content can be diminished to $0.02 \mathrm{wt} \%$. The Raney Ni/C may represent a new type of shaped Raney metal catalysts, which are important fix-bed catalysts in chemical industry.
\end{abstract}

Keywords: carbon-support; Raney nickel; acetone hydrogenation; acidity

\section{Introduction}

Catalysts play key roles in the chemical industry, and more than $90 \%$ of today's chemical processes use catalysts [1,2]. Industrial catalysts have some well-defined features, e.g., activity, selectivity, stability, strength, recoverability, and poison resistance, related to the basic demands of productive process to achieve green, environmental, predictable, and economic operation [3]. Nowadays, it has been realized that the supports, used to disperse and anchor the catalytic active component, play a role in determining the catalytic properties as a result of their physical-chemical properties.

Isopropanol is a commonly used bulk chemical widely used in organic synthesis, industrial solvent, and fuel cells [4-7]. Catalytic acetone hydrogenation is a cheap, safe, and mature alternative method for isopropanol production due to its easy catalytic reduction of $\mathrm{C}=\mathrm{O}$ into $\mathrm{C}-\mathrm{OH}$ [8]. Currently, Raney nickel is adopted as a catalyst for the basic acetone hydrogenation process $[5,8]$. However, powdered Raney nickel cannot be applied in a fix-bed reactor, and is mainly employed in slurry phase reactors for batch productions. Besides Raney nickel, traditional metal/oxide catalysts are also used in acetone hydrogenation, including $\mathrm{Ni} / \mathrm{Al}_{2} \mathrm{O}_{3}$ [9], $\mathrm{Ni} / \mathrm{CeO}_{2}$ [10], $\mathrm{Ni} / \mathrm{SiO}_{2}$ [11], and $\mathrm{Pt} / \mathrm{Fe}_{3} \mathrm{O}_{4}$ [12]. Nevertheless, these tradition metal/oxide catalysts always exhibit acidity due to the intrinsic characteristics of supports. Consequently, acidity always leads to byproducts such as methyl isobutyl ketone (MIBK), methyl isobutylcarbinol (MIBC), isopropyl ether (IPE), and others [13-19], which require a further removal process. Additionally, the reclamation of traditional metal/oxide catalysts requires high-temperature calcination or strong acid/base dissolution, which can potentially cause environmental contamination.

Carbon materials have a variety of advantages (such as stable chemical-mechanical properties, ease with regards to reclamation [20-24]), and have wide applications in the metal catalysts as supports [25-30]. Moreover, the pore structures and surface properties of carbon materials can be adjusted by changing the carbon precursor, adjusting the carbonization temperature, and doping heteroatoms [31,32]. Therefore, a carbon material with weak acidity can be synthesized via the 
above-mentioned methods and used for supporting Raney nickel. In this case, challenges such as the difficulty of using Raney nickel powder in fixed-bed reactors, byproducts formation during the acetone hydrogenation catalyzed by acidity, and environmental contamination aroused from catalyst reclamation could be overcome. Here, a granular carbon-supported Raney nickel catalyst (Raney Ni/C) with weak acidity was prepared via mixing phenolic resin with $\mathrm{Ni}-\mathrm{Al}$ alloy, conducting carbonization at high temperatures, and leaching with alkaline liquor. Then, the Raney Ni/C was characterized by Raman spectra, Scanning Electron Microscopy (SEM), Brunauer Emmett Teller (BET), and $\mathrm{NH}_{3}$ temperature-programmed desorption $\left(\mathrm{NH}_{3}-\mathrm{TPD}\right)$, respectively. Its catalytic properties in terms of acetone hydrogenation were studied at different reaction temperatures and compared with a traditional $\mathrm{Ni} / \mathrm{Al}_{2} \mathrm{O}_{3}$ catalyst.

\section{Results and Discussion}

The microstructure of Raney Ni/C was characterized by Raman spectrum. As shown in Figure 1, there are two bands at $1340 \mathrm{~cm}^{-1}$ (D band) and $1590 \mathrm{~cm}^{-1}$ (G band), which are not separated completely. The $\mathrm{D}$ band corresponds to the common feature of all disordered graphitic carbon, while the $\mathrm{G}$ band represents the graphitic carbon phase with an sp2 electronic configuration [33]. In addition, the relative intensity of both bands reflects the degree of graphitization [34]. Here, the ID/IG of Raney Ni/C is about 3.2, which indicates a low graphitization degree and demonstrates the dominant disordered structure of the carbon support of Raney Ni/C. In the $\mathrm{N}_{2}$-sorption measurements, the specific area and average pore width of Raney Ni/C are determined as $111 \mathrm{~m}^{2} \cdot \mathrm{g}^{-1}$ and $3.3 \mathrm{~nm}$, respectively, by virtue of BET equation; the pore volume is calculated to be $0.092 \mathrm{~cm}^{3} \cdot \mathrm{g}^{-1}$ via Barrett-Joyner-Halenda (BJH) method; and the specific area, average pore width, and pore volume of $\mathrm{Ni} / \mathrm{Al}_{2} \mathrm{O}_{3}$ are $105 \mathrm{~m}^{2} \cdot \mathrm{g}^{-1}, 10.8 \mathrm{~nm}$, and $0.29 \mathrm{~cm}^{3} \cdot \mathrm{g}^{-1}$, respectively. Hence, the Raney Ni/C is mesoporous and possesses a more small-aperture pore structure than $\mathrm{Ni} / \mathrm{Al}_{2} \mathrm{O}_{3}$. SEM image shown in Figure 2 illustrates the porous structure of Raney $\mathrm{Ni} / \mathrm{C}$ as expected. The acidities of both Raney $\mathrm{Ni} / \mathrm{C}$ and $\mathrm{Ni} / \mathrm{Al}_{2} \mathrm{O}_{3}$ were measured by $\mathrm{NH}_{3}-\mathrm{TPD}$ and are shown in Figure 3. Both Raney Ni/C and Ni/Al ${ }_{2} \mathrm{O}_{3}$ show two desorption peaks. Obviously, they have similar weak acidic site desorption peaks at $180{ }^{\circ} \mathrm{C}$; meanwhile, the Raney Ni/C shows a smaller medium-strong acidic sites desorption peak than the $\mathrm{Ni} / \mathrm{Al}_{2} \mathrm{O}_{3}$ at $350{ }^{\circ} \mathrm{C}$ [15]. As proven, the acidity of Raney $\mathrm{Ni} / \mathrm{C}$ is weaker than $\mathrm{Ni} / \mathrm{Al}_{2} \mathrm{O}_{3}$.

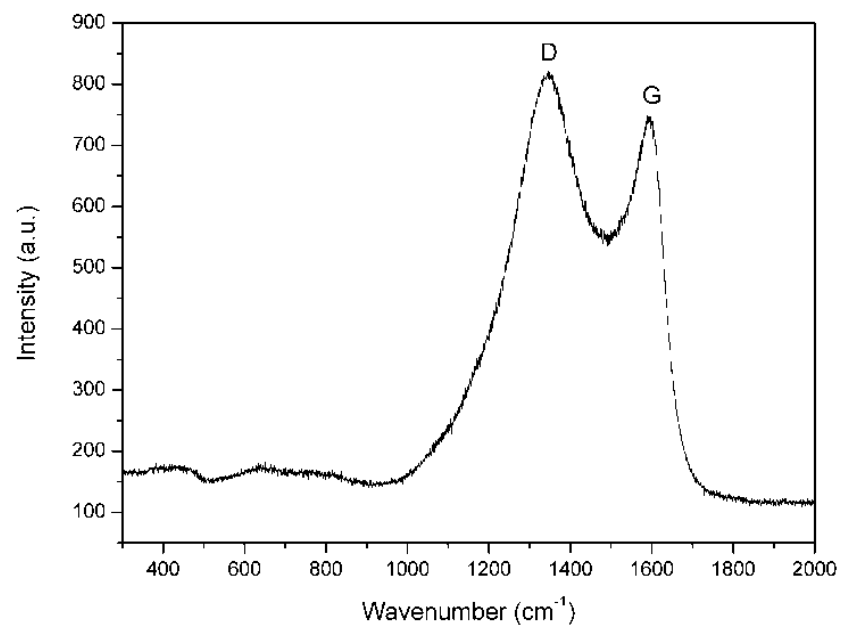

Figure 1. Raman spectrum of Raney Ni/C catalyst. 


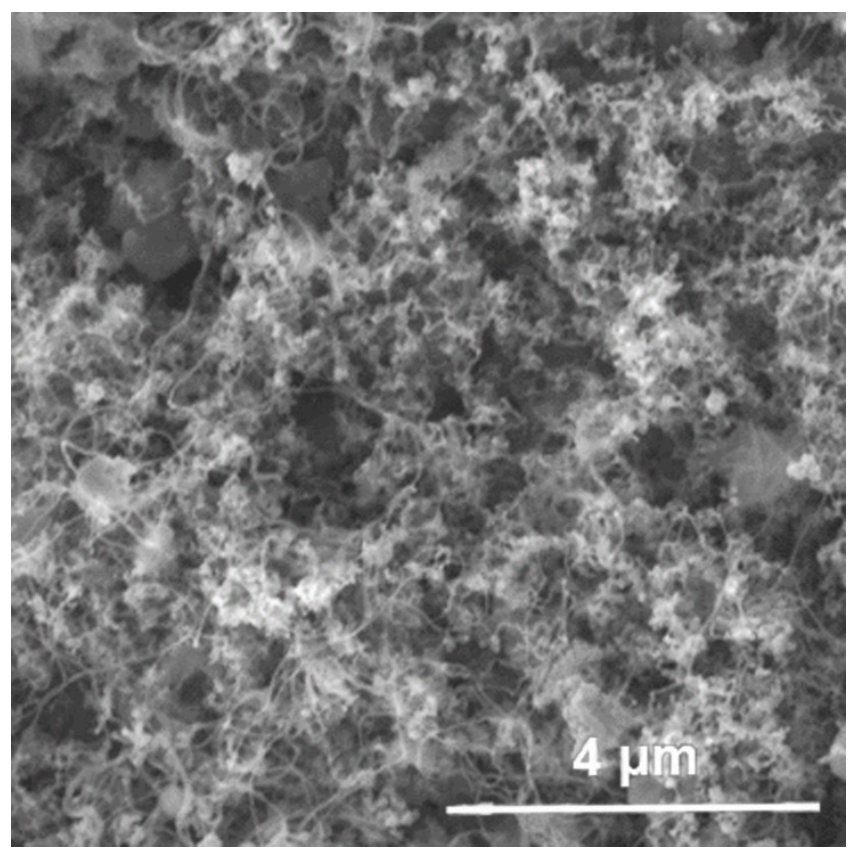

Figure 2. SEM image Raney Ni/C catalyst.

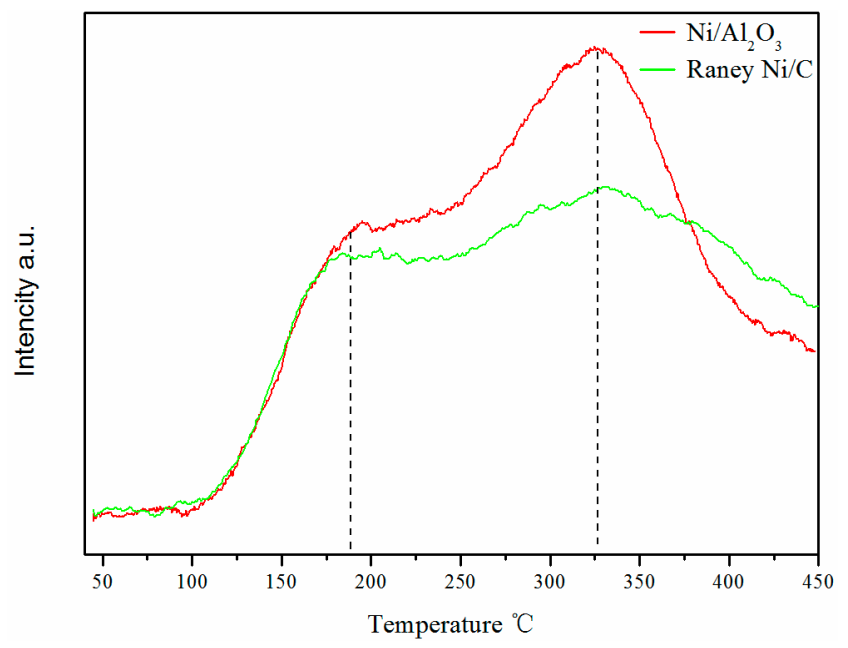

Figure 3. $\mathrm{NH}_{3}-\mathrm{TPD}$ profiles of Raney $\mathrm{Ni} / \mathrm{C}$ catalyst and $\mathrm{Ni} / \mathrm{Al}_{2} \mathrm{O}_{3}$ catalyst.

The numerical results of acetone hydrogenation at $80-150{ }^{\circ} \mathrm{C}$ catalyzed by Raney Ni/C and Ni/ $\mathrm{Al}_{2} \mathrm{O}_{3}$ are listed in Table 1 . The conversion of acetone increases with increasing reaction temperature, and all reach above $99 \%$ at $120-150{ }^{\circ} \mathrm{C}$, indicating the catalytic activity of Raney Ni/C is as high as that of commercialized $\mathrm{Ni} / \mathrm{Al}_{2} \mathrm{O}_{3}$. Moreover, $\mathrm{MIBC}$ is the main byproduct of acetone hydrogenation. When the reaction temperature reached $150{ }^{\circ} \mathrm{C}$, the concentration of MIBC catalyzed by Raney Ni/C was merely $500 \mathrm{ppm}(0.05 \mathrm{wt} \%)$. As for $\mathrm{Ni} / \mathrm{Al}_{2} \mathrm{O}_{3}$, the $\mathrm{MIBC}$ concentration was 56,000 ppm (5.6 wt $\left.\%\right)$ at the same reaction conditions. Obviously, the Raney Ni/C catalyst can reduce the MIBC byproduct of acetone hydrogenation. This can be attributed to the different acidities of catalyst supports attached to carbon and $\mathrm{Al}_{2} \mathrm{O}_{3}$, respectively. Furthermore, in order to testify the effect of acidity on catalytic acetone hydrogenation, a strong acidic cation exchange resin was simply mixed with Raney Ni/C and used as an acetone hydrogenation catalyst. As shown in Table 1, the concentration of MIBC reached up to $150,000 \mathrm{ppm}(15 \mathrm{wt} \%)$. The result confirms the MIBC byproduct is mainly caused by catalyst acidity and the yield of MIBC increases with the increasing catalyst acidity. 
Table 1. Numerical results of acetone hydrogenation catalyzed by Raney $\mathrm{Ni} / \mathrm{C}, \mathrm{Ni} / \mathrm{Al}_{2} \mathrm{O}_{3}$, and mixed catalyst of Raney Ni/C and strong acidic cation exchange resin.

\begin{tabular}{cccc}
\hline Catalyst & Temperature $\left({ }^{\circ} \mathbf{C}\right)$ & Conversion of AC (\%) & MIBC (wt \%) \\
\hline $\mathrm{Ni} / \mathrm{Al}_{2} \mathrm{O}_{3}{ }^{\text {a }}$ & 80 & 94.3 & 0.3 \\
& 100 & 99.9 & 1.9 \\
& 120 & 99.9 & 2.6 \\
& 150 & 99.9 & 5.6 \\
\hline Raney Ni/C & 80 & 76.3 & 0 \\
& 100 & 93.4 & 0.006 \\
& 120 & 99.9 & 0.02 \\
\hline Resin + Raney Ni/C & 150 & 99.9 & 0.05 \\
\hline
\end{tabular}

Reaction conditions: ${ }^{\text {a }} 20 \mathrm{~g}$ acetone, $1 \mathrm{~g} \mathrm{Ni} / \mathrm{Al}_{2} \mathrm{O}_{3}, 3 \mathrm{Mpa} \mathrm{H}_{2}$ pressure, and magnetic stirring $10 \mathrm{~h}^{\mathrm{b}}{ }^{\mathrm{b}} 20 \mathrm{~g}$ acetone, $1 \mathrm{~g}$ Raney Ni/C, $3 \mathrm{Mpa} \mathrm{H}_{2}$ pressure, and magnetic stirring $10 \mathrm{~h}^{\circ}{ }^{\mathrm{c}} 20 \mathrm{~g}$ acetone, $1 \mathrm{~g}$ strong acidic cation exchange resin, $1 \mathrm{~g}$ Raney Ni/C, $3 \mathrm{Mpa} \mathrm{H}_{2}$ pressure, and magnetic stirring $10 \mathrm{~h}$.

\section{Materials and Methods}

In this study, a typical Raney Ni/C was prepared as follows: $2.5 \mathrm{~g} \mathrm{Ni}-\mathrm{Al}$ alloy powder, $10 \mathrm{~g}$ powdery phenol formaldehyde resin, and $1.2 \mathrm{~g}$ hexamethylenetetramine were mixed by a high speed mixer (Zhongcheng pharmaceutical machinery, Changsha, Hunan, China). The mixture was filled into a $2 \mathrm{~mm}$ mold and compressed tightly at a pressure of $5 \mathrm{Mpa}$. Then, a $2 \mathrm{~mm}$-thick plate was obtained. Next, the $2 \mathrm{~mm}$-thick plate was dried at $150{ }^{\circ} \mathrm{C}$ for $30 \mathrm{~min}$, and mechanically cut into particles with a particle size of approximately $2 \mathrm{~mm}$. Finally, granular Raney Ni/C catalyst was obtained through carbonizing the $2 \mathrm{~mm}$ particles at the conditions of $800{ }^{\circ} \mathrm{C}$ and nitrogen atmosphere for $2 \mathrm{~h}$, and aluminum of the carbonized particles was leached using alkaline liquid. The Ni-loading of granular Raney $\mathrm{Ni} / \mathrm{C}$ is $20 \mathrm{wt} \%$. The traditional $\mathrm{Ni} / \mathrm{Al}_{2} \mathrm{O}_{3}$ catalyst was prepared according to the commercial impregnation method. To be specific, $10 \mathrm{~g} \mathrm{Ni}\left(\mathrm{NO}_{3}\right)_{2} \cdot 6 \mathrm{H}_{2} \mathrm{O}$ was dissolved in $3 \mathrm{~g}$ deionized water, to which $10 \mathrm{~g} \mathrm{Al}_{2} \mathrm{O}_{3}$ was added and impregnated for $1 \mathrm{~h}$. The above mixture was dried at $120^{\circ} \mathrm{C}$ for $12 \mathrm{~h}$, followed with calcined at $360^{\circ} \mathrm{C}$ for $4 \mathrm{~h}$. Finally, $\mathrm{Ni} / \mathrm{Al}_{2} \mathrm{O}_{3}$ was obtained after reduced by hydrogen at $400{ }^{\circ} \mathrm{C}$ for $8 \mathrm{~h}$. The Ni-loading of $\mathrm{Ni} / \mathrm{Al}_{2} \mathrm{O}_{3}$ was $20 \mathrm{wt} \%$.

More detailed experimental information, including chemical materials, characterization methods, and hydrogenation experiment, is attached in the supplementary material.

\section{Conclusions}

Raney $\mathrm{Ni}$ is shaped as a granular catalyst by using carbon material as support. This Raney Ni/C can be used in fix-bed reactors, which overcomes the disadvantages of commonly used Raney nickel catalyst. Moreover, the Raney Ni/C can dramatically reduce the MIBC byproduct for catalytic acetone hydrogenation, as a result of the weak acidity of the carbon-support. The recycling of the Raney Ni/C would only need calcining in air to get rid of carbon-support, and the remaining metal alloys could be reused directly. We believe that the preparing method of the granular carbon-supported Raney nickel catalyst could be applied to a series of Raney metal catalysts, for instance, Raney cobalt and Raney copper, which are important fix-bed catalysts in chemical industry.

Supplementary Materials: The following are available online, chemical materials, characterization methods, and hydrogenation experiment.

Author Contributions: Conceptualization, S.L.; methodology, S.L. and Y.C.; investigation, Y.C.; data curation, H.P.; writing — original draft preparation, Y.C.; writing—review and editing, S.L., J.W., H.P., and Y.C. All authors have read and agreed to the published version of the manuscript.

Funding: This research received no external funding.

Conflicts of Interest: The authors declare no conflict of interest. 


\section{References}

1. Cui, X.; Li, W.; Ryabchuk, P.; Junge, K.; Beller, M. Bridging homogeneous and heterogeneous catalysis by heterogeneous single-metal-site catalysts. Nat. Catal. 2018, 1, 385-397. [CrossRef]

2. He, L.; Weniger, F.; Neumann, H.; Beller, M. Synthesis, characterization, and application of metal nanoparticles supported on nitrogen-doped carbon: Catalysis beyond electrochemistry. Angew. Chem. Int. Ed. 2016, 55, 12582-12594. [CrossRef] [PubMed]

3. Lloyd, L. Handbook of Industrial Catalysts; Springer Science and Business Media LLC: New York, NY, USA, 2011; pp. 4-10.

4. Yang, Z.; Chen, W.; Zheng, J.; Yang, Z.; Zhang, N.; Zhong, C.-J.; Chen, B.H. Efficient low-temperature hydrogenation of acetone on bimetallic Pt-Ru/C catalyst. J. Catal. 2018, 363, 52-62. [CrossRef]

5. Rahman, A.; S-Al-Deyab, S. A review on reduction of acetone to isopropanol with Ni nano superactive, heterogeneous catalysts as an environmentally benevolent approach. Appl. Catal. A: Gen. 2014, 469, 517-523. [CrossRef]

6. Ophardt, H.; Loos, V.; Hoogers, G.; Lang, A. Direct isopropanol fuel cell. U.S. Patent 10,230,120, 12 March 2019.

7. Park, H.; Ou, H.-H.; Kang, U.; Choi, J.; Hoffmann, M.R. Photocatalytic conversion of carbon dioxide to methane on TiO2/CdS in aqueous isopropanol solution. Catal. Today 2016, 266, 153-159. [CrossRef]

8. Balouch, A.; Umar, A.A.; Shah, A.A.; Salleh, M.M.; Oyama, M. Efficient Heterogeneous Catalytic Hydrogenation of Acetone to Isopropanol on Semihollow and Porous Palladium Nanocatalyst. ACS Appl. Mater. Interfaces 2013, 5, 9843-9849. [CrossRef]

9. Jiang, H.; Lu, S.; Zhang, X.; Dai, W.; Qiao, J. Polymer-Supported Raney Nickel Catalysts for Sustainable Reduction Reactions. Molecules 2016, 21, 833. [CrossRef]

10. Rao, P.V.R.; Kumar, V.P.; Rao, G.S.; Chary, K.V.R. Vapor phase selective hydrogenation of acetone to methyl isobutyl ketone (MIBK) over Ni/CeO2 catalysts. Catal. Sci. Technol. 2012, 2, 1665. [CrossRef]

11. Witsuthammakul, A.; Sooknoi, T. Selective hydrodeoxygenation of bio-oil derived products: Ketones to olefins. Catal. Sci. Technol. 2015, 5, 3639-3648. [CrossRef]

12. Ji, Y.; Wu, Y.; Zhao, G.; Wang, D.; Liu, L.; He, W.; Li, Y. Porous bimetallic Pt-Fe nanocatalysts for highly efficient hydrogenation of acetone. Nano Res. 2015, 8, 2706-2713. [CrossRef]

13. Zhou, Y.; Duan, H.; Lin, B.; Han, K.; Wei, J. Supported TiO2-Pd bifunctional catalysts for the one-pot synthesis of methyl isobutyl ketone from acetone: Modulation of the acid and base property of loaded TiO2 by support. React. Kinet. Mech. Catal. 2018, 125, 303-317. [CrossRef]

14. Zhang, S.; Wu, P.; Yang, L.; Zhou, Y.; Zhong, H. An efficient bifunctional catalyst of TiO2 coating and supported Pd on cordierite for one-pot synthesis of MIBK from acetone. Catal. Commun. 2015, 71, 61-64. [CrossRef]

15. Ma, R.; Li, Y.; Wu, G.; He, Y.; Feng, J.; Zhao, Y.; Li, D. Fabrication of Pd-based metal-acid-alkali multifunctional catalysts for one-pot synthesis of MIBK. Chin. J. Catal. 2018, 39, 1384-1394. [CrossRef]

16. Narayanan, S.; Unnikrishnan, R. Selective hydrogenation of acetone to methyl isobutyl ketone (MIBK) over co-precipitated Ni/ $\mathrm{Al}_{2} \mathrm{O}_{3}$ catalysts. Appl. Catal. A: Gen. 1996, 145, 231-236. [CrossRef]

17. Yang, S.-M.; Wu, Y.M. One step synthesis of methyl isobutyl ketone over palladium supported on AlPO4-11 and SAPO-11. Appl. Catal. A: Gen. 2000, 192, 211-220. [CrossRef]

18. Shen, Y.; Yi, J.; Yan, Y.; Liu, D.; Fan, L.; Li, S. Hydrogenation and Condensation of Acetone over Ni/MgO- $\mathrm{Al}_{2} \mathrm{O}_{3}$ Prepared from Hydrotalcite Precursors. J. Chem. Eng. Jpn. 2016, 49, 656-662. [CrossRef]

19. Bagabas, A.A.; Mokhtar, M.; Akhmedov, V.M.; Narasimharao, K.; Basahel, S.N.; Al-Rabiah, A. Ru-C-ZnO Composite Catalysts for the Synthesis of Methyl Isobutyl Ketone via Single Step Gas Phase Acetone Self-Condensation. Catal. Lett. 2014, 144, 1278-1288. [CrossRef]

20. Tasis, D.; Tagmatarchis, N.; Bianco, A.; Prato, M. Chemistry of carbon nanotubes. Chem. Rev. 2006, 106, 1105-1136. [CrossRef]

21. Liang, C.; Li, Z.; Dai, S. Mesoporous Carbon Materials: Synthesis and Modification. Angew. Chem. Int. Ed. 2008, 47, 3696-3717. [CrossRef]

22. Georgakilas, V.; Perman, J.A.; Tuček, J.; Zbořil, R. Broad Family of Carbon Nanoallotropes: Classification, Chemistry, and Applications of Fullerenes, Carbon Dots, Nanotubes, Graphene, Nanodiamonds, and Combined Superstructures. Chem. Rev. 2015, 115, 4744-4822. [CrossRef] 
23. Shen, K.; Chen, X.; Chen, J.; Li, Y. Development of MOF-Derived Carbon-Based Nanomaterials for Efficient Catalysis. ACS Catal. 2016, 6, 5887-5903. [CrossRef]

24. Bianco, A.; Chen, Y.; Chen, Y.; Ghoshal, D.; Hurt, R.H.; Kim, Y.A.; Koratkar, N.; Meunier, V.; Terrones, M. A carbon science perspective in 2018: Current achievements and future challenges. Carbon 2018, 132, 785-801. [CrossRef]

25. Liu, X.; Conte, M.; Elias, D.; Lu, L.; Morgan, D.J.; Freakley, S.J.; Johnston, P.; Kiely, C.J.; Hutchings, G.J. Investigation of the active species in the carbon-supported gold catalyst for acetylene hydrochlorination. Catal. Sci. Technol. 2016, 6, 5144-5153. [CrossRef]

26. Contreras-Mora, J.; Banerjee, R.; Bolton, B.K.; Valentin, J.; Monnier, J.R.; Williams, C.T. Characterization and Evaluation of Carbon-Supported Noble Metals for the Hydrodeoxygenation of Acetic Acid. Org. Process. Res. Dev. 2018, 22, 1628-1635. [CrossRef]

27. Perez, R.F.; Soares, O.S.; De Farias, A.M.D.; Pereira, M.F.R.; Fraga, M.A. Conversion of hemicellulose-derived pentoses over noble metal supported on 1D multiwalled carbon nanotubes. Appl. Catal. B: Environ. 2018, 232, 101-107. [CrossRef]

28. Qin, Q.; Heil, T.; Antonietti, M.; Oschatz, M. Single-Site Gold Catalysts on Hierarchical N-Doped Porous Noble Carbon for Enhanced Electrochemical Reduction of Nitrogen. Small Methods 2018, 2, 1800202. [CrossRef]

29. Du, H.; Zhao, C.X.; Lin, J.; Guo, J.; Wang, B.; Hu, Z.; Shao, Q.; Pan, D.; Wujcik, E.K.; Guo, Z. Carbon Nanomaterials in Direct Liquid Fuel Cells. Chem. Rec. 2018, 18, 1365-1372. [CrossRef]

30. Singhania, A.; Bhaskarwar, A.N. Performance of Activated-Carbon-Supported Ni, Co, and Ni-Co Catalysts for Hydrogen Iodide Decomposition in a Thermochemical Water-Splitting Sulfur-Iodine Cycle. Energy Technol. 2018, 6, 1104-1111. [CrossRef]

31. Mironenko, R.M.; Belskaya, O.B.; Likholobov, V.A. Approaches to the synthesis of Pd/C catalysts with controllable activity and selectivity in hydrogenation reactions. Catal. Today 2019. [CrossRef]

32. Wang, X.; Chen, Z.; Zhao, X.; Yao, T.; Chen, W.; You, R.; Zhao, C.; Wu, G.; Wang, J.; Huang, W. Regulation of coordination number over single Co sites: Triggering the efficient electroreduction of CO2. Angew. Chem. Int. Ed. 2018, 57, 1944-1948. [CrossRef]

33. Zhang, J.; Wang, X.; Qi, G.; Li, B.; Song, Z.; Jiang, H.; Zhang, X.; Qiao, J. A novel N-doped porous carbon microsphere composed of hollow carbon nanospheres. Carbon 2016, 96, 864-870. [CrossRef]

34. Shi, M.-M.; Bao, D.; Li, S.-J.; Wulan, B.-R.; Yan, J.-M.; Jiang, Q. Anchoring PdCu Amorphous Nanocluster on Graphene for Electrochemical Reduction of N2to NH3under Ambient Conditions in Aqueous Solution. Adv. Energy Mater. 2018, 8, 1800124. [CrossRef]

Sample Availability: Samples of the compounds are not available from the authors.

(C) 2020 by the authors. Licensee MDPI, Basel, Switzerland. This article is an open access article distributed under the terms and conditions of the Creative Commons Attribution (CC BY) license (http://creativecommons.org/licenses/by/4.0/). 